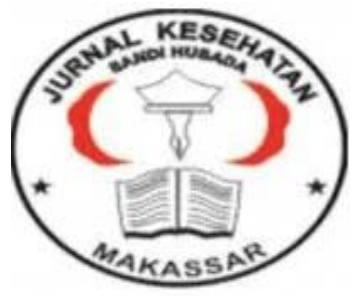

\author{
Jurnal Ilmiah Kesehatan Sandi Husada \\ hhttps://akper-sandikarsa.e-journal.id/JIKSH \\ Vol 9, No, 1, Juni 2020, pp; 13- 17 \\ p-ISSN: 2354-6093 dan e-ISSN: 2654-4563 \\ DOI: $10.35816 /$ jiskh.v10i2.196
}

\title{
Penilaian Status Hidrasi
}

Hydration Assessment

ARTIKEL REVIEW

Annisa Dwianggreni Kusuma

Pendidikan Dokter, Fakultas Kedokteran, Universitas Lampung

\section{Artikel info}

\section{Artikel history:}

Received; 27 Januari 2020

Revised; 27 Januari 2020

Accepted; 27 Januari 2020

\begin{abstract}
Hydration status is a picture of the balance of the entry and exit of water in the body. Water balance is influenced by the amount of food consumed, physical activity, age, and environmental conditions. Dehydration is the loss of large amounts of solute and water. Dehydration can cause the body to get tired quickly, not excited and interfere with physical work activities. Assessing hydration status is very difficult. There are several methods that can be used to determine the concentration of water in the body using laboratory tests and simple checks. Laboratory examination is in the form of isotope tracer, neutron activation analysis, bioelectrical impedance analysis, while simple examination through changes in body weight, hematological indices, urinary indices, and clinical signs and symptoms. This assessment method has advantages and disadvantages for assessing hydration status. Laboratory tests require facilities and expertise to do so, while simple examinations can be carried out by non-medical personnel and can be carried out in the field. Laboratory tests have good specificity and sensitivity compared to simple examination. Laboratory tests have not been able to describe a person's hydration status. A simple combination of laboratory and laboratory tests is needed to determine a person's hydration status.
\end{abstract}

\begin{abstract}
Abstrak.
Status hidrasi merupakan gambaran keseimbangan keluar masuknya air dalam tubuh. Keseimbangan air dipengaruhi dari jumlah makanan yang dikonsumsi, aktivitas fisik, usia, dan kondisi lingkungan. Dehidrasi merupakan hilangnya zat terlarut dan air dalam jumlah yang banyak. Dehidrasi dapat menyebabkan tubuh cepat lelah, tidak bersemangat dan mengganggu aktivitas kerja fisik. Penilaian status hidrasi sangatlah sulit. Terdapat beberapa metode yang dapat untuk mengetahui kosentrasi air dalam tubuh menggunakan pemeriksaan laboratorium dan pemeriksaan sederhana. Pemeriksaan laboratorium berupa isotope tracer, neutron activation analysis, bioelectrical impedance analysis, sedangkan pemeriksaan sederhana melalui perubahan berat
\end{abstract}


badan, hematological indices, urinary indices, dan tanda klinis dan gejala. Metode penilaian ini memiliki kelebihan dan kekurangan untuk menilai status hidrasi. Pemeriksaan laboratorium membutuhkan fasilitas dan tenaga ahli dalam melakukannya, sedangkan pemeriksaan sederhana dapat dilakukan oleh nontenaga medis dan dapat dilakukan di lapangan. Pemeriksaan laboratorium memiliki spesifisitas dan sensitivitas yang baik dibandingkan pemerikasaan sederhana. Pemeriksaan laboratorium belum dapat menggambarkan status hidrasi seseorang. Dibutukan kombinasi pemeriksaan sederhana dan laboratorium untuk menentukan keadaan status hidrasi seseorang.

Keywords:

Dehydration;

Assessment method;

Hydration status;
Coresponden author:

Email: annisakusuma36@gmail.com

artikel dengan akses terbuka dibawah lisensi CC BY -4.0

\section{Pendahuluan}

Air merupakan hal terpenting bagi manusia. Air merupakan 55\% komponen berat tubuh manusia dan berfungsi untuk menjaga hemostasis sel (Popkin, 2010). Selain itu, air memiliki peran sebagai pelarut komponen ion, glukosa dan asam amino, pengangkut nutrisi dan zat sisa, berkonstibusi menjaga temperature tubuh dari perubahan suhu lingkungan serta menjadi campuran mukosa tubuh (Jequier, 2010). Status hidrasi merupakan gambaran keseimbangan keluar masuknya air dalam tubuh (Baron, 2015). Keseimbangan air dipengaruhi dari jumlah makanan yang dikonsumsi, aktivitas fisik, usia, dan kondisi lingkungan. Walaupun tubuh mengatur hidrasi secara ketat, namun dehidrasi tidak dapat dielakkan karena konsumsi cairan yang tidak adekuat (Rielb, 2013).

Dehidrasi merupakan hilangnya zat terlarut dan air dalam jumlah yang banyak (Kenefick, 2012). Dehidrasi dapat menggangu kesehatan dan menyebabkan kematian. Dehidrasi dapat meningkatkan osmolaritas serum secara langsung. Asupan air yang yang kurang dapat dihitung dari pengeluaran air melalui urine, feses, keringat, dan bernapas (Hooper, 2016). Overhidrasi terjadi akibat retensi air dan garam pada beberapa penyakit gastrointestinal, urologi, cardiopulmonary dan atlet (Sharkawy, 2015). Euhidrasi merupakan persamaan TBW normal. Berat badan biasa digunakan untuk memperlihatkan kehilangan air secara akut (Amstrong, 2007). Dehidrasi dapat mempengaruhi kerja organ cardiovascular dan pengaturan termoregulasi tubuh. Dehidrasi dapat menyebabkan tubuh cepat lelah, tidak bersemangat dan mengganggu aktivitas kerja fisik (Murray, 2007).Terdapat beberapa cara keluarnya air dari dalam tubuh yaitu melalui ginjal, kulit, saluran pernapasan, dan sedikit melalui saluran pencernaan. Volume urin dewasa yang dikeluarkan sebanyak 1-2 L selama 24 jam (Jequier \& Constant, 2010).

\section{Metode}

Penulisan tinjauan pustaka menggunakan metode literature review yang dilakukan melalui google dalam bentuk jurnal berbahasa Indonesia maupun inggris 


\section{Hasil Dan Pembahasan}

Terdapat beberapa metode untuk mengetahui kosentrasi air dalam tubuh:

\section{Isoptope Tracer}

Metode penelitian ini menggunakan teori stabilitas isotop yang akan selalu bertukar dengan cairan dalam tubuh dan terdistribusi secara menyeluruh dan dalam jumlah yang stabil selama cairan isotop diberikan. Cairan isotop diberikan secara oral dan akan seimbang dalam tubuh $3-4 \mathrm{~m}$. Setelah itu volume cairan dihitung menggunakan rumus:

$$
\text { PV1 X PC1 = PV2 X Pc2 }
$$

Keterangan : PV (plasma volume), PC(plasma cosentration)

Metode ini dapat menilai Total Body Water, Exttacelluler (ECV) dan Intracelluler (ICV) kompartemen cairan yang berbeda. Pemeriksaan ini tidak dapat menentukan nilai normal hidrasi (Bak, 2017). Tracer yang sering digunakan adalah oksigen $\left(\mathrm{D}_{2} \mathrm{O}\right)$ dan hydrogen $\left(\mathrm{H}_{2} \mathrm{O}\right)$. Tracer hanya akan berdistibusi di ECV dan mendeteksi kadar $\mathrm{Na}$, $\mathrm{Cl}$ dan teutama $\mathrm{Br}$ (Baron et al., 2015).

Neutron Activation Analysis (NAA)

Subjek diletakkan didalam reactor nuklir dan terkena radiasi dalam kadar yang rendah. Pemeriksaan ini menghasilkan radionuklida yang memiki karakteristik sinar yang berbeda. Unsurunsure yang dapat diketahui terutama 98\% kalium dalam ICV datau 90\% klorida dala ECV sehingga volume cairan intravaskuler berbanding lurus dengan cairan ekstravaskuler. Pemeriksaan ini tidak dapat meklasifikasikan ambang batas dari euhydratin (Bak, 2017).

\section{Bioelectrical Impedance Analysis (BIA)}

Metode ini memperkirakan komposisi air dalam tubuh melalui konduksi dari listrik bertegangan rendah. Elektroda diletakkan pada tangan dan kaki. Frekuensi yang dibutuhkan menilai ECV adalah $5 \mathrm{~Hz}$ dan TBW frekuensi yang dibutuhkan $200 \mathrm{~Hz}$. Metode ini dapat menggambarkan komposisi tubuh dan dapat memonitoring perubahan hidrasi dalam interval waktu tertentu (Bak, 2017). Keuntungan merode BIA relative cepat, tidak mahal dan mudah mudah dilakukan. Dalam pemeriksaaan ini pemasangan elektroda sangat mempengaruhi hasil dari ststus hidrasi (Baron et al., 2015).

\section{Perubahan Berat Badan}

Perubahan berat badan diibaratkan dengan perubahan status hidrasi tubuh melalui perubahan jaringan lemak sebagai sumber energy. Pemeriksaan ini merupakan metode yang simple dan menilai hilangnya air saat beraktivitas dalam periode tertentu (Baron et al., 2015). Satu liter lemak yang hilang setara dengan satu kilogram air, sehingga TBW akan berubah dengan cepat. Berat badan akan mudah berubah sesuai konsumsi air dan makanan. Sehingga metode ini akan adekuat dengan penimbangan yang rutin (Bak, 2017). Namun metode ini tidak cocok untuk menilai status hidrasi untuk periode yang lama (Baron et al., 2015).

\section{Hematological Indices}

Metode ini membutuhkan fasilitas yang biasa tersedia di rumah sakit berupa laboratorium dan tenaga ahli. Dalam teorinya, penurunan cairan tubuh akan diikuti oleh penurunan kosentrasi darah. Kenyataannya banyak factor yang mempengaruhi kosentrasi darah meliputi nutrisi dan sisa metabolisme. Dalam hal ini, nilai sodium di ECV mempengaruhi osmolaritas cairannya. Osmolaritas plasma merupakan parameter penilaian status hidrasi. Osmolaritas plasma dapat dihitung dengan rumus :

$$
\text { Osmolality }=2\left(\mathrm{Na} \frac{\mathrm{mmol}}{\mathrm{L}}\right)+2\left(\mathrm{~K} \frac{\mathrm{mmol}}{\mathrm{L}}\right)+\text { Glucose } \frac{\mathrm{mmol}}{L}+\text { Urea mmol/L }
$$

Apabila osmolaritas lebih dari 300 mOsm/Kg menandakan dehidrasi secara klinis (Bak, 2017). 


\section{Urinary Indices}

Ginjal merupakan regulator utama dari kehilangan air karena respondari kenaikan osmolaritas plasma. Terdapat tiga penanda penilaian kosenterasi urine: Osmolaritas urin menggambarkan kosenterasi zat terlarut dlam urine. Pemeriksaan ini dapat mengetahui jumlah zat terlarut ( $\mathrm{Na}, \mathrm{K}$, dan Urea) dan volume air (Baron et al., 2015). Urine Specific Gravity menilai kepadatan urine melalui berat jenis urine dan volume air jernih (Baron et al., 2015). USG merupakan pemeriksaan tunggal yang dapt digunakan dilapangan. USG dapat menilai status hidrasi sesuai dengan keadaan tubuh (Montazer, 2013). Urine Colour pemeriksaan ini menggunakan colour scale dari 1-8 (Baron et al., 2015).

\section{Tanda klinis dan Gejala}

Pengenalan tanda klinis dan gejala memiliki sensitivitas dan spesifisitas yang buruk. Dehidrasi dapat dilihat penurunan turgor kulit ( subclavian dan lengan bawah), takikardi, dan keringnya mukosa mulut (Thomas, 2008), perubahan kebiasaan minum, mata cekung, lemas, mual, muntah, perubahan status mental (Mentes \& Aronow, 2016). Pemeriksaan laboratorium yang digunakan berupa hitung Blood Urea Nitrogen (BUN)/ rasio Kreatinin. Angka normal serum keratin pada dewasa 70.72 $\mathrm{mol} / \mathrm{L}$. Pemeriksaan level serum bikarbonat >13mEq/L (Cavanan, 2009).

\section{Simpulan Dan Saran}

Status hidrasi merupakan gambaran keseimbangan keluar masuknya air dalam tubuh. Status tersebut menggambarkan tubuh kita dalam kondisi dehidrasi/ overhidrasi/ euhidrasi. Untuk mengetahui keadaan tersebut kita membutuhkan pemeriksaan sederhana dan laboratorium sesuai keadaan situasi dan ketersediaan peralatan.

\section{Daftar Rujukan}

Amstrong, L. E. (2007). Assessing Hydration Status : The Elusive Gold Standar. Journal of American Collage of Nutrition, 26(5), 542s-548s.

Bak, Anggie. Tsiami, Amalia. Greene, C. (2017). Methods of Assessment of Hydration Status and Their Usefulness in Detecting Dehydration in the Elderly. Curr Res Nutr Food Sci, 5(2), 4354.

Baron, S., Courbebaisse, M., Lepicard, E. M. ., \& Friedlander, G. (2015). Assessment of Hydration Status In A Large Population. British Journal of Nutrition, 113, 147-158.

Cavanan, A. (2009). Diagnosis And Management of Dehydration in Children. Am Fam Physician, 80(7), 692-696.

Hooper, L. E. all. (2016). Water-loss (Intracellular) Dehydation Assessed Using Urinary Test : How Well Do They Work? Diagnostic Accurancy in Older People. The American Journal of Clinical Nutrition, 104, 121-131.

Jequier, E. ., \& Constant, F. . (2010). Water As an Essential Nutrient: The Physiological Basis of Hydration. European Journal of Clinical Nutrition, 64, 115-123.

Kenefick, R.W.. Cheuvront, S.N.. Leon, K.. O’Brien, K. (2012). Chapter 70 Dehydration And Rehydration. In Wilderness Medicine Textbook. U.S. Army Research Institute of Enviromental Medicine.

Mentes, J. C. ., \& Aronow, H. . (2016). Comparing Older Adults Presenting With Dehydration As A Primary Diagnosis Versus A Secondary Diagnosis In The Emergency Departement. J Aging Res Clin. http://www.jarcp.com/3188-comparing-older-adults-presenting-withdehydration-as-a-primary-diagnosis-versus-a-secondary-diagnosis-in-the-emergencydepartment.html

Montazer, Saideh. Farshad, Ali Asghar. Monazzam, Mohammed Reza. Eyvazlou, Meysam. Yaraghi, Ali Akbar Sabour. Mirkazemi, R. (2013). Assessment of Construction Workers' Hydration 
Status Using Urine Specific Gravity. International Journal of Occupational Medicine and Eviromental Health, 26(5), 762-769.

Murray, B. (2007). Hydration and Physical Performance. Journal of The American Collage of Nutrition, 26(5), 542s-548s.

Popkin, Barry M.. D'Anci, Kristen E.. Rosenberg, I. H. . (2010). Water, Hydration and Health. Nutr Rev, 68(8), 439-458.

Rielb, Shaun K.. Davy, B. M. . (2013). The Hydration Equation: Update on Water Balance and Cognitive Performance. ACSMs Health Fit J, 17(6), 21-28.

Sharkawy, Ahmed M.. Sahota, Opinder. Lobo, D. N. (2015). Acute And Chronic Effect of Hydration Status Health. Nutrition Review, 73, 97-105.

Thomas, D. E. all. (2008). Understanding Clinical Dehydration and Its Treatment. Journal of Medical Directors Association, 9(5), 292-301. 